\title{
The Use of BOST Method as a Tool to Standardize Tasks in Hot Dip Galvanizing Process Im- provement
}

Piotr Sygut, Dorota Klimecka-Tatar, Manuela Ingaldi, Stanisław Borkowski

Institute of Production Engineering, Faculty of Management, Czestochowa University of Technology. ul. Armii Krajowej 19 B 42-200 Czestochova, Poland. E-mail: piotr.sygut.wz@gmail.com, klimt@wip.pcz.pl, manuela@gazeta.pl, bork@ zim.pcz.pl,

Standardization is the basis for improvement in the company. This allows for repeatability performance of activities and thus the stability of the process. This chapter presents the standardization as part of Toyota's production system. Standardization is also one of the elements examined using the method BOST, because it was used for hot dip galvanizing process improvement. The research was carried out in one of the national companies producing steel products and providing services in the field of modern anti-corrosion protection, in particular hot-dip galvanizing.

Keywords: hot-dip galvanizing, BOST method, improvement of production processes

\section{References}

[1] BORKOWSKI, S. (2012). Toyotaryzm. Wyniki badań BOST. Wydawnictwo Menedżerskie PTM. Warszawa.

[2] BORKOWSKI, S., KONSTANCIAK, M. (2010). Toyotarity. Standardization in enterprises. Wyd. Makovetsky, Dnipropetrovsk.

[3] BORKOWSKI, S., ULEWICZ, R. (2008). Zarządzania produkcja, systemy produkcyjne. Wyd. Humanitas, Sosnowiec, 2008.

[4] BORKOWSKI, S., INGALDI. M. (2014). Pojęcie standaryzacji i jej znaczenie. Toyotaryzm. Ujęcie standaryzacji w metodzie BOST. Monografia naukowa. Red. nauk. Stanisław Borkowski, Manuela Ingaldi. Oficyna Wydawnicza Stowarzyszenia Menedżerów Jakości i Produkcji, Częstochowa p. 9-20.

[5] BORKOWSKI, S., SZKLARZYK, P., KONP, K. (2014). Transformation methods of production organization from the far east to the metal industry in Poland, Manufacturing Technology, journal for science, research and production. Volume 14, Issue 2, Pages 125-130.

[6] KLIMECKA-TATAR, D. (2014). The powdered magnets technology improvement by biencapsulation method and its effect on mechanical properties. Manufacturing Technology, journal for science, research and production. March, Volume 14, Issue 1, Pages 30-36

[7] LIKER, J. K. (2005). Droga Toyoty: 14 zasad zarzadzania wiodacej firmy produkcyjnej świata. Wyd. MT Biznes, Warszawa.

[8] SYGUT, P., KLIMECKA-TATAR, D., SZKLARZYK, P. (2013). Round Bars Production Process Improvement Including the Toyota Management Principles. Toyotarity. Evoluation and Processes'/Products' Improvement. Monograph. Scientific Editors Stanisław Borkowski, Manuela Ingaldi. p. 95-105.

[9] SYGUT, P., LABER, K., BORKOWSKI, S. (2012). Investigation of the non-uniform temperature distribution on the metallic charge length during round bars rolling process, Manufacturing Technology, journal for science, research and production. December. Vol. 12, No 13, s. 260-263. 